\title{
Avoid Becoming a Dinosaur that is Important in Change Management: Dinosaur Syndrome
}

\author{
Değişim Yönetiminde Önemli Olan Dinozorlaşmamak: Dinozor Sendromu
}

\author{
Özgür Yeşilyurt*
}

\begin{abstract}
Change in business organizations may emerge due to both economic and environmental conditions. Another condition that necessitates change is technological developments. The subject of change is sometimes tried to be prevented by being exposed to the employees' resistance. This study aims to examine the conceptual framework of the dinosaur syndrome in the context of change management. We thought that employees' dislike of change and innovations and attempt to prevent them leads them to dinosaur syndrome. Dinosaur syndrome refers to the resistance to change that can be seen in business organizations along with individuals. It should not be forgotten that the basis of the dinosaur syndrome seen in business organizations is also the employees. Dinosaur syndrome emerges in three stages. The first stage consists of encountering, confrontation, and disharmony, and the second stage of resistance to change and rejection of change. And finally, the third stage consists of clumsinessdownsizing, extinction, transformation into another organization. In conclusion, the success of change depends on placing the change as a lifestyle in the business culture, including employees in the change processes as much as possible, and their participative management approach.
\end{abstract}

Keywords: Change in Business, Change Management, Dinosaur Syndrome, Innovation Management.

Öz: İşletmelerde değişim gerek ekonomik gerekse çevresel koşullardan dolayı ortaya çıkabilmektedir. Değişimi zorunlu kılan diğer bir koşul da teknolojik gelişmelerdir. Değişim konusu bazen çalışanların direncine maruz kalarak engellenemeye çalışılmaktadır. Bu çalışmanın amacı değişim yönetimi bağlamında dinozor sendromunun kavramsal çerçevesinin irdelenmesidir. Çalışanların değişimi ve yenilikleri sevmemesi ve engellemeye çalışması durumunun çalışanları dinozor sendromuna yönlendirdiği düşünülmektedir. Dinozor sendromu bireylerde görüldüğü gibi organizasyonlarda da görülebilen değişim karşısındaki direnci ifade etmektedir. Organizasyonlarda görülen dinozor sendromunun temelinde de yine çalışanların olduğu unutulmamalıdır. Dinozor sendromu üç evrede ortaya çıkmaktadır. Birinci evre; karşılaşma, yüzleşme ve uyumsuzluk, ikinci evre; değişim karşısında direnme ve değişimi reddetme, üçüncü evre ise; hantallaşma-küçülme, yok olma, bir başka örgüte dönüşümdür. Sonuç olarak; değişimin başarısı değişimin bir yaşam tarzı olarak işletme kültürü içerisine yerleştirilmesine, çalışanların değişim süreçlerine mümkün olduğunca dahil edilmelerine ve katılımcı yönetim anlayışına sahip olmalarına bağlıdır.

Anahtar Kelimeler: İşletmelerde Değişim, Değişim Yönetimi, Dinozor Sendromu, Yenilik Yönetimi.

\footnotetext{
*Asst. Prof. Dr., Social Work Department, Faculty of Health Sciences, Muş Alparlsan University ORCID: 0000-0001-9252-3375, o.yesilyurt@alparslan.edu.tr

Received/Geliş: 01 July/Temmuz 2021

Accepted/Kabul: 03 August/Ağustos 2021

Düzeltme/Revised form: 23 July/Temmuz 2021

Published/Yayın: 31 August/Ağustos 2021
}

e-ISSN: 2149-4622. @ 2013-2021 Muş Alparslan Üniversitesi. TÜBİTAK ULAKBİM DergiPark ev sahipliğinde. Her hakk1 saklıdır. http://dx.doi.org/10.18506/anemon.960568 


\section{Introduction}

Globalization concomitantly has provided the disappearance of national borders, and has expanded the areas addressed by the change phenomenon. Rapid change has necessitated change and innovations both individually and organizationally. Keeping up with the conditions of the information society and change, and seeing the risks and threats are vital for the survival of the business operator. In other words, positive and negative situations in the rate of change of corporate performance determine the fate of business organizations. One of the key considerations in adapting to change is the adoption of change by employees in the business. The openness of business employees to change and innovation will facilitate the survival of the business under all circumstances (Çınar, 2020: 159).

When considering the historical process, business organizations must follow technological changes closely in using their production resources optimally and increasing their productivity. Although the changes in information technologies were used a lot in the labor-intensive sectors in the past, today it started to replace brainpower. Internet of things technology and artificial intelligence are crucial in terms of providing digital transformation in business organizations.

The intensive use of information technologies in the information society brought along by globalization has necessitated the change of their organizational structures. Organizational structures emphasizing the participative management approach try to involve the employees, who are the most crucial element of change, in the business. When considered in this context, including employees in change processes with a participative management approach shall both enable adoption of the changes by the employees, and increase the success of the change. Another situation that will lead business organizations to success in change is the correct analysis of the internal and external environment. It is quite difficult for business organizations that cannot see the opportunities and threats around change or do not know their strengths and weaknesses to be successful in change. Managers in the business must accept that change is inevitable and continuous, and should guide the business organization in this direction.

It is the gospel truth that technologies, that make easy every stage of life, also enable the business process of organizations. We know that the effects of changes, which are increasing day by day especially due to technological developments, will increase in the future (Yeşilyurt, 2021: 178). This change cycle, which means a redesign of fundamental business processes and economic boundaries in the information society, also necessitates people to change. Today, the change in information technologies has been used as a competitive element with the influence of globalization. The speed of change in technologies is increasing day after day, and it makes the opening of new business areas to business organizations in the global context easy. Advances in information technologies have made it possible for business organizations to go beyond limits. It means that the world has turned into a small village and enables business organizations to take service to distant corners of the world. With the increase in transportation and carriage opportunities, the concept of time and distance has disappeared.

Resistance can occur in terms of change in both individual and organizational contexts. Elimination of this resistance and using change as a competitive tool by the business organization will be possible by following a good change management policy. The success of the change arising from internal and external factors will be possible by correctly explaining and adopting the change to the employees. The study aims to clarify the dinosaur syndrome, which represents change management and individual and organizational resistance to change, and examine it with support from the literature. In addition, it is the suggestion of solutions for the elimination of this resistance.

\section{Change Management in Business}

Business organizations compete with their competitors by keeping up with a constantly changing world and struggle to survive. The speed of change, its dynamism, risks, and complexity force business organizations to change. The important thing here is that business organizations understand the environment and adapt to change by internalizing it (Yeşil, 2013: 19). 
In the history of humanity, social life was experienced with the effect of scientific and technological developments, and with these developments, the management philosophy and management approach of the business organizations have changed. This change accelerated after World War II. Both the importance and the spreading speed of information have increased through the developments in information technologies. Moreover, information was considered as productive capital, and today it has begun to be evaluated as the most significant production factor. Business organizations aimed to grow and survive by integrating information into their production processes (Tunçer, 2011: 3).

Changes in information technologies and business organizations have provided a rapid change in business environments in recent years. This state of change has brought about restructuring in both the internal and external environment in the business organization (Tekin and Ömürbek, 2016: 40).

The situation of change in enterprises includes some challenges due to the requirement of behavioral change in employees. To overcome these challenges, employees should be informed about the change process, and the change should be internalized by the employees. The stages of the corporate change process are as follows (Tekin and Ömürbek, 2016: 39):

- Feeling the need for change,

- Making decisions related to change,

- Beginning of the change process.

In terms of management, it would be more accurate to discuss change as a process. The learning situation underlying the change requires balancing at the level of knowledge. Therefore, business organizations may change their product range, production methods, and organizational structure, especially considering external factors. The most significant factor that will lead business organizations to success in change is the adoption of this change as a form of life. Another crucial issue of change is that it should be institutionalized and adopted as a culture to the entire enterprise (Demir, 2008: 286). We observed that technological developments and processes that follow the change, which cause the disappearance of the borders and the concept of time between countries, come to the fore and significantly increase profitability level. This wind of change, which increases the interaction of the business organizations, forces them to invest in these areas (Yeşilyurt, 2020: 129).

The factors that are efficient in change management in business organizations are internal factors and external factors. In Figure 1, the factors that are efficient in change management are given.

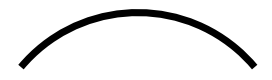

\section{Effective Factors in Change Management}

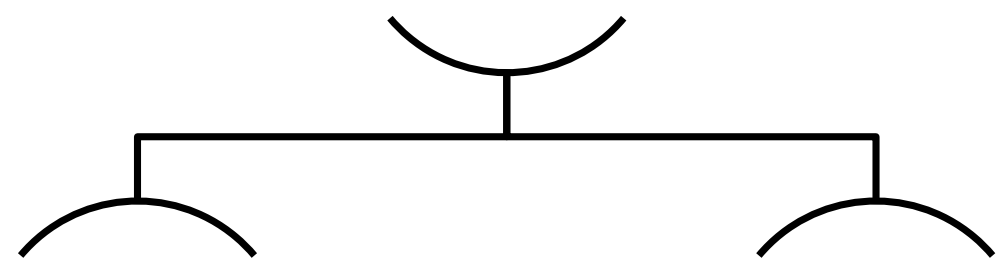

Internal factors: Factors emerged and shaped within the framework of the employees' wishes.

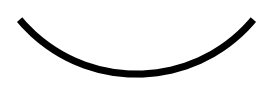

External Factors: Factors arisen and shaped by the environment in which the business interacts.

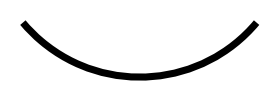

Figure 1: Effective Factors in Change Management 
Source: Created by the author

When examining the source of change, although it is considered that external factors come to the forefront in general, internal factor's existence also should not be forgotten.

When considered in this context, although the change is actually initiated by external factors, internal factors are effective on whether or not this change is accepted. In other words, the factors that persuade business organizations to change can be considered as internal factors. When considered in this context, the main factor of change forms the basis of change and the motivation to change in people. What makes change compulsory is actually the information society we live in.

The information society is also called the post-industrial society and the post-modern society. The information society has emerged with its own rules and principles (Özata and Sevinç, 2010: 1). It would be a more accurate approach to evaluate the subject of change as an advantage of the information society and the information age. In the information society, the factors that lead business organizations to change and/or compel them to adopt are as follows:

- National or international crises,

- Developments in information technologies,

- The removal of economic boundaries (globalization),

- Change in business processes brought about by the information society.

\section{Dinosaur Syndrome}

The situation encountered by individuals and business organizations by trying to prevent change is called the dinosaur syndrome. Since the dinosaur metaphor, which typifies individuals and organizations that cannot renew itself, also represents an extinct being, it also represents size and clumsiness and symbolizes extinction. This syndrome essentially refers to a fatal disease caught in an individual and organizational context. This disease should be diagnosed and treated quickly to avoid serious results (Çınar, 2020: 160).

Dinosaur syndrome brings along adverse outcomes. One of these adverse outcomes is the inability of static structures that do not keep up with environmental changes to create sustainable value. In order to eliminate these negativities, it is significant to review the activities, monitor the opportunities for change, and establish a dynamic structure for change (Naktiyok, 2007: 214).

Figure 2 shows the characteristic features of the dinosaur syndrome. 


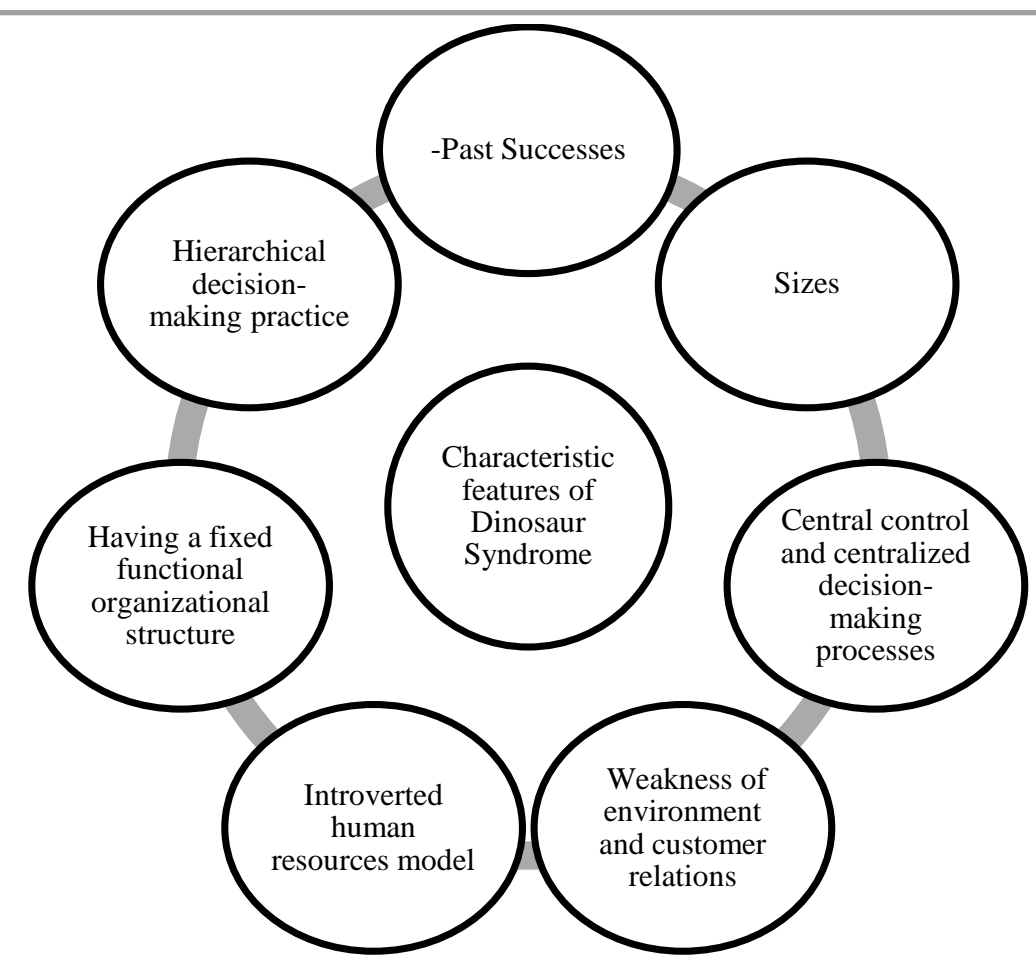

Figure 2: The Characteristic Features of the Dinosaur Syndrome

Source: Created by the author, using (Gökbunar and Ünal, 1999: 47-48).

Inferential statements about the characteristic features of dinosaur syndrome are as follows (Gökbunar and Ünal, 1999: 47-48):

Past successes: past successes are an obstacle for business organizations to take opportunities for change. We should not forget that the basis of past success is due to success in change management. Past successes should not cause dinosaur syndrome as an obstacle to future success.

Sizes: the size of the business organizations brings along clumsiness. In the case of clumsiness, it is difficult for business organizations to make change and innovations sustainable.

Central control and centralized decision-making processes: centralized management style can bring about communication problems and prevent a participative management approach.

Weakness of environment and customer relations: business organizations that cannot correctly assess the changes in the environment, customer requests, and expectations cannot keep up with the change and cause the business organization to have the dinosaur syndrome.

Introverted human resources model: one of the most important activities of human resources management is personnel selection. In the introverted human resources model, which expresses the training of employees within the business organization, wrong employee selection can cause dinosaur syndrome, even if employees are trained within the business organization.

Having a fixed functional organizational structure: numerous departments in the business organization make it difficult to provide coordination in it. Failure to ensure harmony between departments can harm the business.

Hierarchical decision-making practice: hierarchical decision-making structure causes troubles in decision processes. Having troubles in the decision-making process also makes it difficult to follow the change in the business.

Peterson (2016) discussed the dinosaur syndromes in the business organization under three titles 
- Dinosaurs get stuck.

- Dinosaurs are coldblooded.

- Dinosaurs are unchanging.

Development Process of Dinosaur Syndrome and Precautions to be Taken Against This Syndrome

Dinosaurs became extinct due to external environmental conditions. This extinction shows that the dinosaurs could not keep up with the environmental conditions. The process of organizations with dinosaur syndrome consists of three stages (Çınar, 2020: 161-165).

- First Stage: encountering, Confrontation, and Disharmony Stages: it represents the stage in which the change is encountered for the first time. Happenings outside the business do not interest the employees. This stage represents the first stage of the dinosaur syndrome. At this stage, dinosaur syndrome is avoidable through precautions to be taken. It includes encountering, confrontation, and disharmony stages.

- Second Stage: resistance to Change and Rejection of Change Stage: it represents the stage in which business organizations come closest to dinosaurization. The lack of a leader, who correctly perceives the change processes in the business, is considered as a factor increasing resistance to change. Employees with limited vision play a determining role in the fate of the business organization. It includes the stages of resistance and rejection of change.

- Third Stage: clumsiness-Downsizing, Extinction, Transformation into Another Organization: the inevitable ending of business organizations that reject change is clumsiness-downsizing, extinction, and transformation into another organization. It is the last stage of dinosaur syndrome.

Considering the development process of dinosaur syndrome, in Figure 3, the precautions to be taken during encountering, confrontation, and disharmony are given.

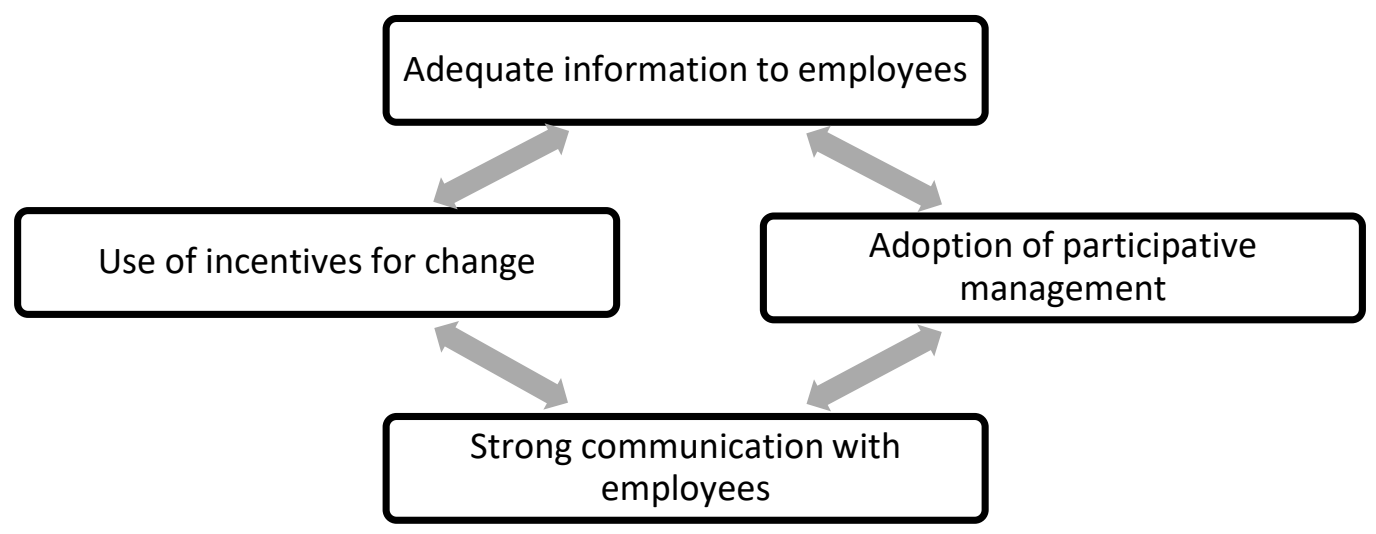

Figure 3: Precautions to be taken against Dinosaur Syndrome

Source: Created by the author syndrome:

Precautions to be taken in order to prevent the change from being affected by the dinosaur

- Adequate information to employees: employees should be adequately informed by the change team. Since change generally scares people and leads to dinosaur syndrome, this fear should be eliminated with information. 
- Adoption of participative management: involving employees in change processes will facilitate the internalization of change and increase success in change management. Having employees as a part of the change will reduce the barriers to change.

- Strong communication with employees: emphasizing the issue of explaining the change by the leaders who manage the change will increase the acceptability of the change.

- Use of incentives for change: the use of monetary incentives in the change management process shall remove people's prejudices about change and the situation where they get the dinosaur syndrome.

\section{Evaluation and Conclusion}

The history of humanity is evaluated in four periods: primitive society, agricultural society, industrial society, and information society. Social and economic conditions determine the characteristics of these societies. It would be correct to consider the change in the environmental and cultural context for seeing the limits of the information society. We see that information is applied intensively to the production processes in the information society. The most important factor shaping the information society is the change in information and communication technologies. Business processes have been redesigned with the use of the internet in the information society. This situation contributed to the emergence of different organizational structures and the restructuring of the management philosophy.

Business organizations need to produce new strategies to compete in economic fluctuations and crisis environments (Budak and Budak, 2018: 152). Changing environmental conditions and technological developments are also considered as another factor that compels business organizations to change. The most crucial factor that leads business organizations to success in change management is the transformation of change into a lifestyle in the organization. Points to take into consideration are to adopt the change as a culture to all units in the business.

We should not forget that technological change and globalization are the leading factors that make change compulsory. These factors concern business organizations as well as individuals. Business organizations need to keep up with the changes in the national and international context by creating new strategies. Keeping up with the change is considered by the business organization as the most significant competitive element. Another factor that triggers the change in the environment. In order not to cause environmental problems, in other words, to protect the environment, business organizations have to change.

The basic dynamic in change is the change in economic activities. In the past, both the agricultural revolution and the industrial revolution brought about changes in the economic structure. In today's society, expressed as an information society, it has made it compulsory for business organizations to use information and communication tools because the use of information technologies in the information society necessitated the redesign of business processes. It increased the possibilities of access and communication through the internet in the information society. It has led to the emergence of situations that will prevent change. The spread of information pollution about change, described as gossip, has made it difficult for business management to implement changes since it is harder to verify and eliminate misinformation than inform people about change. Information pollution and lack of communication cause an increase in resistance to change. This situation brings along the dinosaur syndrome.

All employees can't accept the change that expresses differentiation in business organizations. There will be opponents to change among employees. Their situations of the change should be evaluated, and why they oppose the change should be revealed (Tengilimoğlu et al., 2020: 353). Undoubtedly, the most crucial factor in the wind of change is the employees who did not prevent this change. Failure to keep up with and prevent this change, defined as the dinosaur syndrome, is a situation faced by business organizations. Dinosaur syndrome can occur in individuals as well as in organizations. It is significant to reveal this situation clearly and diagnose correctly in the first stage (encountering, confrontation, and disharmony phase). In case of late diagnosis, it is impossible to save individuals and business organizations that resist change. It means that the business organization cannot compete with its 
competitors. Therefore, the dinosaur syndrome must be determined on time, and a way must be found to explain the change correctly to people.

\section{References}

Budak, G. \& Budak, G. (2018). İşletme yönetimi. Ankara: Nobel Akademik Yayınc1lık.

Çınar, H. (2020). Dinozor sendromu. N. CEMALOĞLU (Ed.), Sendromların eğitim ve yönetime yansımaları. (159-173) içinde Ankara: Pegem Akademi.

Demir, Y. (2008). İşletme yönetimi açısından değişim mühendisliği yaklaşımı ve uygulanabilirliği. Social Sciences Business Administration. 3(2), 286-295.

Gökbunar, R. \& Ünal, A. G. (1999). Yönetimde dinazorlaşma sendromu ve kamu yönetiminde değişim. Atatürk Üniversitesi İktisadi ve İdari Bilimler Dergisi, 13(1), 45-58.

Naktiyok, A. (2007). Yenilik yönelimi ve örgütsel faktörler. Atatürk Üniversitesi İktisadi ve İdari Bilimler Dergisi, 21(2), 211-230.

Özata, M. \& Sevinç, İ. (2010). Türk kamu yönetiminde bilgi sistemleri ve e-dönüşüm. Konya: Eğitim Akademi Yayınları.

Peterson, B. (2016). 3 Signs that your company's a dinosaur -- and how to evolve. Erișim Tarihi: 10.06.2021. https://www.inc.com/ben-peterson/3-signs-that-your-companys-a-dinosaur--andhow-to-evolve.html

Tekin, M. \& Ömürbek, N., (2016). Endüstri 4.0’da teknoloji yönetimi. Konya: Günay Ofset.

Tengilimoğlu, D., Atilla, E. A. \& Bektaş, M. (2020). İşletme yönetimi temel kavramlar çă̆daş yaklaşımlar işletme ve yönetim fonksiyonları. Ankara: Seçkin Yayıncılık.

Tunçer, P. (2011). Yönetimde değişim ve değişim yönetimi teknikleri. Bursa: Ekin Yayınevi.

Yeşil, S. (2013). Küreselleşme ve değişen çevre dinamikleri ışı̆̆ı̆nda yeni yönetim yaklaşımlarından seçme konular. Ankara: Seçkin Yayıncılık.

Yeşilyurt, Ö. (2020). Endüstri 4.0 bağlamında sağllk hizmetleri ve yönetiminde nesnelerin interneti teknolojisi. N. YILMAZ \& M. N. SALUR (Ed.). Endüstri 4.0 perspektifinden işletme fonksiyonları ve dijital dönüşüm. (115-134) içinde Konya: Necmettin Erbakan Üniversitesi Kültür Yayınları.

Yeşilyurt, Ö. (2021). Sağlık hizmetleri ve yönetiminde yapay zeka uygulamaları. E. GELMEZ \& N. YILMAZ (Ed.) Endüstri 4.0 bakışıyla üretim yönetimi seçme yazılar. (177-198) içinde Konya: Çizgi Kitabevi. 